3 Tappin DM, King C, Paton JY. Lower oesophageal pH monitoring-a useful clinical tool. Arch Dis Child 1992;67:146-8.

4 Evans DF, Robertson CS, Ledingham SJ, Kapila L. Oesophageal pH monitoring for gastrooesophageal reflux: a United Kingdom study. $\mathcal{J}$ Pediat Suring for gastrooes

5 Cucchiara S, Staiano A, Boccieri A, et al. Effects of cisapride on parameters of oesophageal motility and on prolonged intraoesophageal $\mathrm{pH}$ test in infants oesophageal motility and on prolonged intracesophageal
with gastro-oesophageal reflux disease. Gut 1990;31:21-5.

6 Samuels MP, McClaughlin W, Jacobson RR, Poets CF, Southall DP. Fourteen cases of imposed airway obstruction. Arch Dis Child 1992;67:
. $162-70$.

7 Sacre L, Vandenplas Y. Gastrooesophageal reflux associated with respiratory abnormalities during sleep. F Pediatr Gastroenterol Nutr 1989;9:28-33.

8 Veereman-Wauters G, Bochner A, Caillie-Bertrand MV. Gastrooesophagea reflux in infants with a history of near-miss sudden infant death. $\mathcal{F}$ Pediat Gastroenterol Nutr 1991;12:319-23.

9 Newman LJ, Russe J, Glassman MS, et al. Patterns of gastrooesophagea reflux (GER) in patients with apparent life-threatening events. $\mathcal{J}$ Pediat Gastroenterol Nutr 1989;8:157-60

10 See CC, Newman LJ, Berezin S, et al. Gastrooesophageal reflux-induced hypoxemia in infants with apparent life-threateing event(s). $A m \mathcal{F}$ Dis Child 1989;143:951-4.

11 Paton JY, Macfayden U, Williams A, Simpson H. Gastro-oesophageal reflux and apnoeic pauses during sleep in infants-no direct relation. Eur $M$ and apnoeic pauses during

12 Sondheimer JM, Hoddes E. Electroencephalogram patterns during sleep reflux in infants. Gastroenterology 1991;101:1007-11.

13 Joiley $\bar{S} \overline{\mathbf{G}}$, Herbst JJ, Johnson DG, Matlack ME, Book LS. Esophageal pH monitoring during sleep identifies children with respiratory symptoms from gastrooesophageal reflux. Gastroenterology 1981;80:1501-6.

14 Halpern LM, Jolley SG, Tunell WP, Johnson DG, Sterling CE. The mean duration of gastrooesophageal reflux during sleep as an indicator of respiratory symptoms from gastrooesophageal reflux in children. $\mathcal{F}$ Pediatr Surg 1991; 26:686-90.

15 Jolley SG, Halpern LM, Tunell WP, Johnson DG, Sterling CE. The risk of sudden infant death from gastrooesophageal reflux. $\mathcal{F}$ Pediatr $S$ urg 1991;26: 691-6.

16 Jolley SG, Johnson DG, Herbst JJ, Matlack ME. The significance of gastrooesophageal reflux patterns in children. $\mathcal{F}$ Pediatr Surg 1981;16:859-65.

17 Menon AP, Schefft GL, Thach BT. Apnoea associated with regurgitation in infants. F Pediatr 1985; 106:625-9.

18 Herbst JJ, Minton SD, Book LS. Gastrooesophageal reflux causing respiratory distress and apnoea in newborn infants. $\mathcal{F}$ Pediatr 1979;95:763-8.
19 Newell SJ, Booth IW, Morgan MEI, Durbin GM, McNeish AS. Gastrooesophageal reflux in pre-term infants. Arch Dis Child 1989;64:780-6.

20 Ajuriaguwerra ME, Radvanyi-Boubet M-F, Houn C, Moriette G. Gastrooesophageal reflux and apnoea in prematurely born infants during wakefulness and sleep. Am $\mathcal{I}$ Dis Child 1991;145:1132-6.

21 Perkett EA, Vaughan RL. Evidence for a laryngeal chemoreflex in some human pre-term infants. Acta Paediatr Scand 1982;71:969-72.

22 Fontan JP, Heldt GP, Hetman MB, Marin MS, Toolet WH. Esophageal spasm associated with apnoea and bradycardia in an infant. Pediatrics 1984; 73:52-5.

23 Schey WL, Replogle R, Campbell C. Eosophageal dysmotility and the sudden infant death syndrome: clinical experience. Radiology 1981;140:67-71.

24 Goodwin SR, Graves SA, Haberkern CM. Aspiration in intubated premature infants. Pediatrics 1985;75:85-8.

25 Newell SJ, Morgan MEI, Durbin GM, Booth IW, McNeish AS. Does mechanical ventilation precipitate gastro-oesophageal reflux during enteral feeding? Arch Dis Child 1989;64:1352-5.

26 Abrahams P, Burkitt BFE. Hiatus hernias and gastrooesophageal reflux in children and adolescents with cerebral palsy. Australian Paediatric fournal 1976;41-6.

27 Halpern LM, Jolley SG, Johnson DG. Gastrooesophageal reflux: a significant association with central nervous system disease in children. $\mathcal{J}$ Pediatr Surg 1991;26:171-3.

28 Staino A, Cucchiara SH, Del Giudice E, Andreotti MR, Minella R. Disorders of oesophageal motility in children with psychomotor retardation and gastro-oesophageal reflux. Eur $\mathcal{F}$ Pediatr 1991;150:638-41.

29 Puntis JWL, Smith HL, Buick RG, Booth IW. Effects of dystonic movement on oesophageal peristalsis in Sandifer's syndrome. Arch Dis Child 1989;64: on oesophat $1311-3$.

30 Berezin S, Medow MS, Glassman MS, Newman LJ. Chest pain of gastrointestinal origin. Arch Dis Child 1989;63:1457-60

31 Castell DO. 'But doctor, if it is not my heart, what is it?' European foumal of Gastroenterology and Hepatology 1991;12:897-8.

32 Brueton MJ, Clarke GS, Sandhu BK. Effect of cisapride on gastrooesophageal reflux in children with and without neurological disorders. Dev Med Child Neurol 1990;32:629-32.

33 Pearl RH, Robie K, Ein SH, et al. Complications of gastrooesophageal antireflux surgery in neurologically impaired versus neurologically normal children. F Pediatr Surg 1990;25:1169-73.

34 Rice H, Seashore JH, Touloukian RJ. Evaluation of Nissan fundoplication in neurologically impaired children. 7 Pediatr Surg 1991;26:697-701.

35 Stringel G, Delgado M, Guertin L, Cook JD, Marabilla A, Worthen H. Gastrostomy and Nissen fundoplication in neurologically impaired Gastrostomy and Nissen fundoplication
children. P Pediatr Surg 1989;24:1044-8.

\title{
Excitatory amino acid neurotoxicity-a broader horizon for cerebral protection?
}

Substantial experimental evidence accumulated over the past decade indicates that an endogenous mechanism of toxicity, which results in a selective neuronal lesion more severe in dendrites than in axons (with sparing of glia), may be significant in the process of neuronal degeneration seen after brief neurological insults. Much of the evidence has been pharmacological with protection from the development of morphological neuronal injury by the use of antagonists acting specifically at the glutamate family of neuronal receptors. 12 The powerful protective effects of these antagonists are potentially of great clinical significance, and could have a role in the treatment of cerebral ischaemia, profound hypoglycaemia, and status epilepticus. In the immature brain, however, the potential usefulness of these agents may be precluded by their adverse effects on behaviour and brain development, because of the importance of excitatory neurotransmission in neuronal outgrowth, plasticity, and cell to cell interaction. ${ }^{3}$ Despite such potential limitation for treatment, an understanding of the mechanism of excitatory amino acid neurotoxicity takes us significantly closer to conceptualising the process of neuronal death induced by acute insults, which must be central to any cerebral protective measures.

\section{The 'excitotoxic' hypothesis}

In its simplest form the so called 'excitotoxic' hypothesis of neuronal injury proposes that glutamate or other related endogenous excitatory neurotransmitters become toxic in their interaction with glutamate receptors, resulting in a cascade of intracellular events that culminate in neuronal death. ${ }^{4-8}$ What makes an endogenous transmitter (which is normally released into and cleared from the synaptic cleft) become a neurotoxin is still a matter of much speculation, but these events may be attributable to:

(1) an excessive build up of extracellular glutamate because of abnormal neurotransmitter release, or abnormal uptake by neurons and glia;

(2) abnormal glutamate receptor activation because of abnormal postsynaptic sensitivity;

(3) abnormal induction and amplification of intracellular cytotoxic events.

\section{Glutamate receptors}

There is evidence for multiple subtypes of excitatory neurotransmitter receptors, which are commonly called glutamate receptors, as glutamate is the most widely accepted endogenous agonist. These receptors can be divided into three groups. There are two classes which possess an intrinsic ion channel, called ionotropic receptors. These are the $N$-methyl-D-aspartate (NMDA) receptor and the non-NMDA, kainate/quisqualate receptor, which are presumed to be large, multisubunit integral membrane protein complexes, which possess receptor binding sites with a central ion channel. The third class of receptor is the metabotropic glutamate receptor, which instead of possessing an intrinsic ion channel exerts its action through second messenger systems by activation of a G-protein.

An understanding of the extent to which these glutamatereceptor subtypes contribute to the neuronal injury induced by acute cerebral insults has been facilitated by experimental 
studies that have evaluated the relative neurotoxicity produced by intracerebral injection of specific receptor agonists, NMDA, quisqualate, and kainate. The results indicate major ontogenic alterations in the excitatory amino acid pathways, with different brain regions and neuronal types exhibiting their own developmental profile of susceptibility to each of the glutamate-receptor agonists. Comparing NMDA with non-NMDA agonists, on an equimolar basis, the greater degree of injury in the immature brain is produced by NMDA, and in the developed brain by nonNMDA agonists. ${ }^{9-11}$ Furthermore, in the immature brain, there appears to be a transient overproduction of glutamatereceptor synaptic terminals, which may not only account for periods of heightened synaptic plasticity and consolidation of synaptic connections, but also provide a molecular substrate for increased susceptibility to particular insults. ${ }^{3}$

\section{Glutamate-receptor antagonists}

Of all the major classes of glutamate receptor, the best antagonists were first found for the NMDA receptor subtype. Consequently, most is known about the potential role of this receptor in mediating the neuronal injury of acute brain insults. It should, however, be remembered that many of the antagonists are not 'pure' in their differentiation between the receptor subtypes, particularly at higher concentrations, and so any beneficial effect may not be solely mediated by antagonism of a specific receptor subtype. In addition to the obvious interest in the pharmacologically 'designed' antagonists, which have for the time being only proved to be useful experimental tools, there has been some recent experimental ${ }^{12}{ }^{13}$ and clinical ${ }^{14}$ interest in those agents already in clinical usage that have a known antagonistic effect on the NMDA receptor channel complex. These drugs are considerably less potent than the experimental agents, and include ketamine and dextromethorphan (phencyclidine site ligands) and magnesium.

\section{Excitotoxicity and acute cerebral insults}

Cerebral ischaemia, profound hypoglycaemia, and status epilepticus, result in a complex interaction between changes in cerebral energy metabolism, cerebral blood flow, bloodbrain barrier function, neuronal depolarisation, and glialneuronal interaction. As already mentioned, the main evidence that an excitotoxic mechanism provides a crucial link in the sequence of events leading to neuronal loss after these insults is pharmacological. Several studies have demonstrated that glutamate-receptor blockade can prevent neuronal injury induced by a variety of acute insults in both the mature and immature brain. Although the most well characterised insult is ischaemia, interaction at a single subtype of glutamate receptors cannot explain the findings in all the experimental models of hypoxic-ischaemic insult. As an example, it has been observed that there is a relative lack of neuroprotection with NMDA antagonists in some adult models of cerebral ischaemia. ${ }^{7} 15$ These findings would be consistent with a model of glutamate-receptor mediated toxicity that takes into account the ontogenic profiles of neuronal injury due to exogenous glutamatereceptor agonists; ischaemia induced injury would be expected to be predominantly mediated by NMDA receptors in the immature brain and by non-NMDA receptors in the adult brain.

An excitotoxic process has also been implicated in profound hypoglycaemia and status epilepticus. In hypoglycaemia it seems likely that neurotoxicity is mediated by the NMDA receptor with aspartate as the endogenous agonist. ${ }^{16} 17$ That glutamate-receptor antagonists are also potent anticonvulsants suggests involvement of these recep- tors in the mechanism of toxicity induced by status epilepticus. This speculative hypothesis, however, would be impossible to test with receptor antagonists, as blockade of glutamatergic neurotransmission for neuroprotection would also stop the epileptic activity. There has therefore been much effort in trying to demonstrate an abnormal accumulation of excitatory amino acids in the extracellular space during the period of insult.

\section{The wider horizon for cerebral protection}

This annotation has so far presented the barest model of excitatory amino acid neurotoxicity induced by acute cerebral insults, with the NMDA receptor providing a central role in the process of neuronal injury. Having illustrated some of the pharmacological evidence supporting the recent interest in the NMDA receptor, it is also worth noting that this receptor has unusual physiological properties. Because the receptor ion channel is blocked by normal concentrations of extracellular magnesium, the NMDA receptor is difficult to activate. Only as the membrane becomes depolarised and the magnesium blockade is lifted, can the receptor be activated. The ion channel then allows calcium to enter the cell. The resultant rise in cytosolic calcium is considered to be the initiating step in the cascade of intracellular events that culminate in neuronal death. ${ }^{78}$

The excitotoxic mechanism of neuronal injury has gained a broader interest beyond acute cerebral insults because of recent observations that indicate that neurons can be made more susceptible to the excitotoxic effects of glutamate and other related excitatory amino acids by manipulations of cellular energy metabolism and membrane potential. ${ }^{18}$ It has been suggested that impairment of cellular energy metabolism leads to failure of the $\mathrm{Na}+/ \mathrm{K}+$ ATPase that maintains the normal membrane potential, resulting in membrane depolarisation, reduced magnesium blockade, and easier activation of NMDA receptors. ${ }^{18-20}$ The process of neuronal death could be initiated by impairment of cellular metabolism or membrane potential with an excitotoxic process being the final common pathway of neuronal death: an attractive hypothesis for chronic neurodegenerative disorders such as Huntington's disease and Parkinson's disease.

As our understanding of neuronal injury produced by excitatory amino acids has grown, experimenters have used glutamate receptor antagonists as pharmacological tools to explore the role of endogenously triggered excitotoxicity in the complex pathophysiology of brain injury following acute cerebral insults. Although the knowledge gained from such experimental models and tissue culture may ultimately be translated into practical clinical strategies for the treatment of acute brain injury, there is potentially a far wider application in chronic neurodegenerative disease, and some inherited metabolic disorders.

ROBERT C TASKER

Paediatric Intensive Care Unit,

Hospital for Sick Children,

Great Ormond Street,

London WCIN $3 \mathcal{F H}$

1 Simon RP, Swan JH, Griffiths T, Meldrum BS. Blockade of N-methyl-d. 1984;226:850-2.

2 Wieloch T. Hypoglycemia-induced neuronal damage prevented by an $\mathrm{N}$-methyl-D-aspartate antagonist. Science 1985;230:681-3.

3 McDonald JW, Johnston MV. Physiological and pathophysiological roles of excitatory amino acids during central nervous system developroles of excitatory amino acids during cen

4 Lucas DR, Newhouse JP. The toxic effect of sodium L-glutamate on the inner layers of the retina. Arch Ophthalmol 1957;58:193-201.

5 Olney JW. Brain lesion, obesity and other disturbances in mice treated with Olney JW. Brain lesion, obesity and other disturbance

6 Rothman SM. Synaptic release of excitatory amino acid neurotransmitter mediates anoxic neuronal death. $\mathcal{F}$ Neurosci $1984 ; 4: 1884-91$. 
7 Choi DW. Cerebral hypoxia: some new approaches and unanswered questions. F Neurosci 1990;10:2493-501.

8 Manev H, Costa E, Wroblewski JT, Guidotti A. Abusive stimulation of excitatory amino acid receptors: a strategy to limit neurotoxicity. $F A S E B \mathcal{J}$ 1990;4:2789-97.

9 Campochiaro P, Coyle JT. Ontogenic development of kainate neurotoxicity: correlates with glutamatergic innervation. Proc Natl Acad Sci USA 1978; 75:2025-9.

10 Silverstein FS, Chen RC, Johnston MV. The glutamate agonist quisqualic acid is neurotoxic in striatum and hippocampus of immature rat brain. Neurosci Lett 1986;71:13-8.

11 McDonald JW, Silverstein FS, Johnston MV. Neurotoxicity of N-methyl-Daspartate is markedly enhanced in developing rat central nervous system. Brain Res 1988;459:200-3.

12 Prince DA, Feeser HR. Dextromethorphan protects against cerebral infarction in a rat model of hypoxia-ischemia. Neurosci Lett 1988;85:291-6.

13 McDonald JW, Roeser NF, Silverstein FS, Johnston MV. Quantitative assessment of neuroprotection against NMDA-induced brain injury. Exp Neurol 1989;106:289-96.
14 Oliya Y, Ochi N, Mizutani N, Hayakawa C, Watanabe K. Non-ketotic hyperglycinemia: treatment with NMDA antagonist and consideration of neuropathogenesis. Pediatr Neurol 1991;7:65-8.

15 Sheardown MJ, Nielsen EO, Hansen AJ, Jacobsen P, Honore T. 2,3Dihydroxy-6-nitro-7-sulfamoyl-benzo (F) quinoxaline: a neuroprotectant for cerebral ischemia. Science 1990;247:571-4.

16 Auer RN. Progress review: hypoglycemic brain damage. Stroke 1986;17: 699-708.

17 Tasker RC, Coyle JT, Vornov JJ. The regional vulnerability to hypoglycemiainduced neurotoxicity in organotypic hippocampal culture: protection by early tetrodotoxin or delayed MK-801. F Neurosci 1992 (in press).

18 Henneberry RL, Novelli A, Cox JA, Lysko PG. Neurotoxicity at the $\mathrm{N}$-methy-D-aspartate receptor in energy-compromised neurons. 'An hypothesis for cell death in aging and disease. Ann N Y Acad Sci 1989;568 225-33.

19 Beal MF. Does impairment of energy metabolism result in excitotoxic neuronal death in neurodegenerative illnesses? Ann Neurol 1992;31:119-30.

20 Albin RL, Greenamyre JT. Alternative excitotoxic hypotheses. Neurology 1992;42:733-8. 